\title{
Corneal endothelial cells changes in different stages of Keratoconus: a multi- Centre clinical study
}

\author{
Ahmed Elmassry ${ }^{1 *}$, Ahmed Osman ${ }^{1}$, Moataz Sabry², Mohamed Elmassry ${ }^{3}$, Mai Katkat ${ }^{1,4}$, \\ Mohamed Yousry Hatata ${ }^{1}$ and Mohamed El-Kateb ${ }^{1,4}$
}

\begin{abstract}
Purpose: To assess the corneal endothelial cells morphology and count in keratoconus patients and their correlation with different stages of keratoconus.

Methods: Prospective non randomized multi-centric clinical study included 150 eyes of 150 keratoconus patients. Four centers in Egypt participated in this study included: Departments of Ophthalmology in Alexandria University, Tanta University and Port Said University and Alex I-Care hospital. Pentacam (Wavelight Oculyzer II) and specular microscopy (Tomey EM-3000) were done to all eyes. Keratoconic eyes were classified according to Amsler classification into stage 1, 2 and 3. Stage 1 included 99 eyes, stage 2 included 32 eyes \& stage 3 included 19 eyes.

Results: The mean age of keratoconus patients was $24.07 \pm 6.154$ years. Forty five cases were males (30\%) and 105 cases were females (70\%). There was statistically significant difference in endothelial cell density $(p<0.001)$ and coefficient of variation ( $p=0.012$ ) between different stages of keratoconus eyes. Regarding cell surface area, there was statistically significant difference in cell surface area between different stages of keratoconus eyes $(p<0.001)$. In addition, for cell morphology, there was statistically significant difference between different stages of keratoconus eyes $(p<0.001)$.

Conclusions: Qualitative and quantitative structural changes were seen in endothelial cells of keratoconus eyes by using specular microscopy. For stages 1 and 2, keratoconus may not affect the corneal endothelim significantly. The endothelium in stage 3 shows significant changes regarding polymegathism and pleomorphism.
\end{abstract}

Keywords: Corneal endothelial cells, Keratoconus, Specular microscopy

\footnotetext{
* Correspondence: ahmad.elmassry@gmail.com

${ }^{1}$ Department of Ophthalmology, Faculty of Medicine, Alexandria University, Champollion Street, Al Attarin, Alexandria, Egypt

Full list of author information is available at the end of the article
}

(c) The Author(s). 2021 Open Access This article is licensed under a Creative Commons Attribution 4.0 International License, which permits use, sharing, adaptation, distribution and reproduction in any medium or format, as long as you give appropriate credit to the original author(s) and the source, provide a link to the Creative Commons licence, and indicate if changes were made. The images or other third party material in this article are included in the article's Creative Commons licence, unless indicated otherwise in a credit line to the material. If material is not included in the article's Creative Commons licence and your intended use is not permitted by statutory regulation or exceeds the permitted use, you will need to obtain permission directly from the copyright holder. To view a copy of this licence, visit http://creativecommons.org/licenses/by/4.0/. The Creative Commons Public Domain Dedication waiver (http://creativecommons.org/publicdomain/zero/1.0/) applies to the data made available in this article, unless otherwise stated in a credit line to the data. 


\section{Introduction}

Keratoconus (KC) is a corneal disorder with a noninflammatory nature. The reported prevalence is one in 2000 people globally and showed variability among studies [1-10]. Although $\mathrm{KC}$ has a world-wide distribution, it was reported more in specific groups such as South Asians, North Africans, and Eastern Mediterranean [11-13].

There are variable rates of the progression between individuals and severe stages of the disease are not supposed to occur for everyone. In $10-15 \%$ of patients, it may reach for severe stages with required transplantation to get functional vision [1-10].

Corneal endothelium in humans acts as a one layer of uniformed cells having a hexagonal shape and covers the posterior surface of the cornea. Its function is to stabilize the hydration of corneal and confirm the transparency. As endothelial cells are not usually reproducible, the surrounding cells will replace both space and activity of dead cells. Consequently, age and pathologies affects the total cells number, regular tessellation, and their size [14].

The cornea health state can be described through analyzing morphometric parameters for the endothelium of the cornea which gives clinical relevant data. Likewise, endothelial density of cell, polymegethism (or variation coefficient, cell size differences expressed as fractional standard deviation of cell areas), together with pleomorphism (or hexagonality coefficient, hexagonal cells fraction over the total cells number) are parameters commonly used to characterize the condition of the endothelial cells quantitatively [15]. Confocal microscopy and in-vivo specular allow getting non-invasive images for the corneal endothelial layer of humans, from which morphometric parameters and density can be derived [16].

DALK represents a successful transplantation form with healthy endothelium [17-20]. When abnormalities in corneal endothelium are present in $\mathrm{KC}$ patients, these may theoretically affect the maintenance of the clarity for corneal graft in the long-term after DALK. When we correlate the grade of the disease with the extent of endothelial abnormality, this may change the criteria for selecting DALK. Therefore, in advanced abnormal endothelium, PK along with donor tissue of high-quality may be a better choice compared to DALK. Confocal microscopy and specular microscopy [21].studies have shown abnormal endothelium in patients with $\mathrm{KC}$. The aim of this study was to assess the corneal endothelial cells morphology and count in $\mathrm{KC}$ patients and their correlation with different stages of $\mathrm{KC}$.

\section{Patients and method}

This prospective non comparative multi-centric clinical study included 150 eyes of 150 keratoconus patients. Four centers in Egypt participated in this study included:
Departments of Ophthalmology in Alexandria University, Tanta University and Port Said University and Alex I-Care center between January 2019 and February 2020. The protocol of this study was accepted and approved by the Ethics Committee of Faculty of medicine, Alexandria University, Egypt on January 17th, 2019 with IRB No. 00012098, FWA No. 00018699 and Serial No. 0304218.

Keratoconic eyes were classified into 4 stages according to the classification of Amsler-Krumeich:

\section{Stage 1}

Eccentric bulging of the cornea, myopia and/ or astigmatism less than $5 \mathrm{D}$, corneal radius less than or equal to 48 D, no corneal opacities and Vogt's striae.

\section{Stage 2}

Myopia and/ or astigmatism more than $5 \mathrm{D}$ and less than $8 \mathrm{D}$, corneal radius less than or equal to $53 \mathrm{D}$, no central opacities and pachymetry at least $400 \mathrm{um}$.

\section{Stage 3}

Myopia and or astigmatism more than $8 \mathrm{D}$ and less than $10 \mathrm{D}$, corneal radius more than $53 \mathrm{D}$, no central opacities and pachymetry 200-400 um.

\section{Stage 4}

Refraction difficult to determine, the radius of corneal more than $55 \mathrm{D}$, central scars and pachymetry less than 200 um.

Exclusion criteria included eyes with history of contact lens wearing, previous ocular surgeries, acute hydrops, previous collagen crosslinking and eyes with stage 4 keratoconus because of the corneal opacities that will interfere with accurate data captured by specular microscopy. There were no patients with forme fruste keratoconus (unilateral KC) included in our study.

Informed consents were obtained from all the participants in our study. Every patient was subjected to full ophthalmological examination included uncorrected and corrected distance visual acuity, examination by slitlamp, corneal topography and thickness data from Scheimpflug camera (Oculyzer II, Wavelight Inc.). Corneal endothelial cells data where captured from the cornea and centered over the cone using non contact specular microscopy (Tomey EM-3000). The data obtained from the specular microscopy were the following:

Cell Density (CD): is defined as the density of the analyzed endothelial cells as number of cells per $1 \mathrm{~mm}$.

Coefficient of Variation (CV): of the analyzed endothelial cells, derived by dividing standard deviation by the average dimension.

Polymegathism: is defined as the difference in sizes and distribution of endothelial cells dimensions. From 
the output of polymegathism data, 200-300 um ${ }^{2}$ surface area cells percentage, $300-400 \mathrm{um}^{2}$ surface area cells percentage and $400-500 \mathrm{um}^{2}$ surface area cells percentage were selected.

Plemorphism: is defined as the difference and distribution of endothelial cells shapes. From the output of plemorphism data, pentagonal, hexagonal and heptagonal cell morphology were be selected.

\section{Statistical analysis}

Data were collected and analyzed using SPSS program for statistical analysis version 25. Kolmogorov-Smirnov test was used to check the normal distribution and when showed no significance, we used parametric statistics. Otherwise, the non-parametric statistics was used.

Data were described using mean, standard deviation, range for the normally distributed data and median and inter-quartile range for non-normally distributed data. Categorical data were described as frequency and percentage of total. For more than two groups, comparisons, One-way Analysis of Variance (ANOVA) test was used for normally distributed data with post-hoc multiple comparisons when ANOVA test was significant. Kruskal-Wallis (KW) test was used for non-normally distributed data with post-hoc pair-wise comparisons when KW is significant using Dunn-Bonferroni test for multiple comparisons. We adopted a randomly selected eye per a case to avoid inter-eye correlation [22, 23].

\section{Results}

\section{Age and sex}

The mean age of keratoconus patients was $24.07 \pm 6.154$ with range from 16 to 45 years. As regards the sex distribution, 45 cases were males (30\%) and 105 cases were females (70\%).

\section{Endothelial cell density (ECD) (cells $/ \mathrm{mm}^{2}$ )}

Table 1 shows comparison between different stages of keratoconus and endothelial cell density (ECD). There was statistically significant difference in endothelial cell density between different stages of keratoconus eyes $(p<0.001)$.

\section{Coefficient of variation (CV) (\%)}

Table 1 shows comparison between different stages of keratoconus and coefficient of variation (CV). There was statistically significant difference in coefficient of variation between different stages of keratoconus eyes $(p=$ 0.012).

\section{Cell surface area $200-300$ um $^{2}(\%)$}

Table 2 shows comparison between different stages of keratoconus and cell surface area 200-300 um ${ }^{2}$ (\%). There was statistically significant difference in cell
Table 1 Comparison between different stages of keratoconus eyes according to the endothelial cell density and coefficient for variation

\begin{tabular}{|c|c|c|c|}
\hline & $\begin{array}{l}\text { Stage } 1 \\
(n=99)\end{array}$ & $\begin{array}{l}\text { Stage } 2 \\
(n=32)\end{array}$ & $\begin{array}{l}\text { Stage } 3 \\
(n=19)\end{array}$ \\
\hline \multicolumn{4}{|c|}{ Endothelial cell density (ECD) } \\
\hline Range & $2193-3434$ & 2143-2971 & $1782-2654$ \\
\hline Mean \pm S.D & $2734.25 \pm 284.25$ & $2453.25 \pm 274.41$ & $2344.05 \pm 396.14$ \\
\hline$P$ value & $<0.001$ & & \\
\hline P1 & $<0.001$ & & \\
\hline P2 & $<0.001$ & & \\
\hline P3 & 0.625 & & \\
\hline \multicolumn{4}{|c|}{ Coefficient of Variation (CV) } \\
\hline Range & $27-83$ & $34-56$ & $31-44$ \\
\hline Mean \pm S.D & $38.45 \pm 12.35$ & $44.84 \pm 6.02$ & $38.32 \pm 5.28$ \\
\hline$P$ value & 0.012 & & \\
\hline P1 & 0.011 & & \\
\hline P2 & 1 & & \\
\hline P3 & 0.106 & & \\
\hline
\end{tabular}

P1 comparison between stage 1 and stage 2

$P 2$ comparison between stage 1 and stage 3

P3 comparison between stage 2 and stage 3

surface area 200-300 um ${ }^{2}$ between different stages of keratoconus eyes $(p<0.001)$.

Cell surface area $300-400$ um $^{2}(\%)$

Table 2 shows comparison between different stages of keratoconus and cell surface area 300-400 um ${ }^{2}$ (\%). There was statistically significant difference in cell surface area $300-400 \mathrm{um}^{2}$ between different stages of keratoconus eyes $(p<0.001)$.

Cell surface area $400-500$ um $^{2}(\%)$

Table 2 shows comparison between different stages of keratoconus and cell surface area 400-500 $\mathrm{um}^{2}$ (\%). There was statistically significant difference in cell surface area $400-500 \mathrm{um}^{2}$ between different stages of keratoconus eyes $(p=0.002)$.

\section{Pentagonal cell morphology (\%)}

Table 3 shows comparison between different stages of keratoconus and pentagonal cell morphology (\%). There was statistically significant difference in pentagonal cell morphology between different stages of keratoconus eyes $(p<0.001)$.

\section{Hexagonal cell morphology (\%)}

Table 3 shows comparison between different stages of keratoconus and hexagonal cell morphology (\%). There was statistically significant difference in hexagonal cell morphology between different stages of keratoconus eyes $(P<0.001)$. 
Table 2 Comparison between different stages of keratoconus eyes according to cell surface area

\begin{tabular}{|c|c|c|c|}
\hline & $\begin{array}{l}\text { Stage } 1 \\
(\mathrm{n}=99)\end{array}$ & $\begin{array}{l}\text { Stage } 2 \\
(n=32)\end{array}$ & $\begin{array}{l}\text { Stage } 3 \\
(n=19)\end{array}$ \\
\hline \multicolumn{4}{|c|}{ Cell surface area $\left(200-300 \mathrm{um}^{2}\right)$} \\
\hline Range & $17-42$ & $17-31$ & $10-24$ \\
\hline Mean \pm S.D & $26.91 \pm 7.46$ & $21.09 \pm 5.27$ & $17.37 \pm 5.73$ \\
\hline$P$ value & $<0.001$ & & \\
\hline P1 & $<0.001$ & & \\
\hline P2 & $<0.001$ & & \\
\hline P3 & 0.188 & & \\
\hline \multicolumn{4}{|c|}{ Cell surface area $\left(300-400 \mathrm{um}^{2}\right)$} \\
\hline Range & $1-1.2$ & $1-1.2$ & $1-1.2$ \\
\hline Mean \pm S.D & $29.04 \pm 3.81$ & $24 \pm 2.3$ & $21.47 \pm 4.54$ \\
\hline$P$ value & $<0.001$ & & \\
\hline P1 & $<0.001$ & & \\
\hline P2 & $<0.001$ & & \\
\hline P3 & 0.054 & & \\
\hline \multicolumn{4}{|c|}{ Cell surface area $\left(400-500 \mathrm{um}^{2}\right)$} \\
\hline Range & $12-30$ & $11-29$ & $19-26$ \\
\hline Mean \pm S.D & $20.62 \pm 4.72$ & $20.5 \pm 5.12$ & $24.68 \pm 1.6$ \\
\hline$P$ value & 0.002 & & \\
\hline P1 & 1 & & \\
\hline P2 & 0.001 & & \\
\hline P3 & 0.005 & & \\
\hline
\end{tabular}

$P 1$ comparison between stage 1 and stage 2

P2 comparison between stage 1 and stage 3

P3 comparison between stage 2 and stage 3

\section{Heptagonal cell morphology (\%)}

Table 3 shows comparison between different stages of keratoconus and heptagonal cell morphology (\%). There was statistically significant difference in heptagonal cell morphology between different stages of keratoconus eyes $(p=0.014)$.

\section{Discussion}

In the present study, we discussed the relation between different stages of keratoconus and endothelial cells changes as regarding the endothelial cell density, coefficient for variation (CV), polymegathism and pleomorphism.

Our study included 150 eyes of $150 \mathrm{KC}$ patients. The $\mathrm{KC}$ eyes were classified into 4 stages according to Amsler's classification. Stage 4 eyes were not included in the study because of the permanent scarring that interferes with specular microscopic images.

Since keratoconus is an ectatic disease affecting both the anterior and posterior corneal surfaces, there might be changes in corneal endothelial cell number and morphology, especially in advanced stages of the disease.
Table 3 Comparison between different stages of keratoconus eyes according to cell morphology

\begin{tabular}{cccc}
\hline & $\begin{array}{l}\text { Stage 1 } \\
(\mathbf{n}=\mathbf{9 9})\end{array}$ & $\begin{array}{l}\text { Stage 2 } \\
(\mathbf{n}=\mathbf{3 2})\end{array}$ & $\begin{array}{l}\text { Stage 3 } \\
\mathbf{( n = 1 9 )}\end{array}$ \\
\hline Pentagonal cell morphology & & \\
Range & $14-27$ & $16-24$ & $19-27$ \\
Mean \pm S.D & $19.72 \pm 3.16$ & $20.69 \pm 3.23$ & $24.37 \pm 2.43$ \\
P value & $<0.001$ & \\
P1 & 0.378 & \\
P2 & $<0.001$ & \\
P3 & $<0.001$ & \\
\hline
\end{tabular}

\section{Hexagonal cell morphology}

$\begin{array}{llll}\text { Range } & 30-61 & 33-48 & 28-40 \\ \text { Mean } \pm \text { S.D } & 48.74 \pm 8.61 & 40.03 \pm 5.29 & 32.42 \pm 5.29 \\ \text { value } & <0.001 & & \\ \text { P1 } & <0.001 & & \\ \text { P2 } & <0.001 & & \\ \text { P3 } & 0.002 & & \end{array}$

Heptagonal cell morphology

\begin{tabular}{clll} 
Range & $17-26$ & $14-28$ & $17-26$ \\
Mean \pm S.D & $20.75 \pm 2.55$ & $22.28 \pm 4.71$ & $22.68 \pm 4.02$ \\
$P$ value & 0.014 & & \\
P1 & 0.074 & \\
P2 & 0.064 & \\
P3 & 1 & & \\
\hline
\end{tabular}

$P 1$ comparison between stage 1 and stage 2

$P 2$ comparison between stage 1 and stage 3

P3 comparison between stage 2 and stage 3

In keratoconus, evaluation of the corneal endothelium may be important since theoretically these cells may be damaged as a result of microscopic ruptures in Descemet's membrane in ectatic areas, ultraviolet radiation damage due to stromal thinning, chronic eye rubbing, long-term contact lens wear, and oxidative stress [22].

\section{Endothelial cell density (ECD)}

In our study the analysis of ECD in different stages of keratoconus revealed significant difference. Only 5 studies compared ECD in different stages of $\mathrm{KC}$ in the literature. Timucin et al. [24], Niederer et al. [25] and ElAgha et al. [26] found no significant difference in ECD between mild, moderate and severe stages of KC. While Uçakhan et al. [27] and Bitirgen G [28] found significant reduction in ECD in severe stages when compared with mild and moderate stages of keratoconus.

\section{Coefficient of variation (CV) and Polymegathism}

In our study, there were statistically significant differences between coefficient of variation $(\mathrm{CV})$ and different stages of keratoconus. El-Agha et al. [26] found that CV 
to be from 22 to $67 \%$ and was higher in stage 3. However, this difference was not of statistical significance $(p=0.51)$.

Hollingsworth et al. [29] found that the level of polymegethism in endothelium present in the $\mathrm{KC}$ eye was found to be as for matched controls $(p=0.08)$. Their results are consistent with the findings of Halibis [30]. He showed that the level of polymegethism in KC subjects is not different compared to of lens-wearing subjects. None of the previous studies or others have however tried to correlate the degree of polymegathism in endothelium with the stage of $\mathrm{KC}$.

In our study we analysed the polymegathism results according to cell surface area of the endothelial cells in keratoconic eyes. Our results revealed significant difference between eyes with different stages of keratoconus.

\section{Pleomorphism}

The hexagon is the polygon with the greatest surface area in relation to its perimeter. Hence, it is an efficient cell shape for covering a given area. In normal cornea, $60 \%$ of the endothelial cells are expected to be hexagons. Decrease to the normal distribution of $60 \%$ for 6 sided cells to a lesser percentage can be the result of stress to the endothelial cells.

Our results revealed significant difference between eyes with pleomorphism and different stages of keratoconus. Conversely, Laing et al. [21] used specular microscopy to study the corneal endothelium in 12 eyes with KC. The finding showed an increase for the pleomorphism of cells with some of the cells smaller compared to normal and considerably distributed through the endothelial cell population. Likewise, Matsuda et al. [21] found that hexagonal cells in keratoconus were significantly lower than that of controls and also there was a significant increase in the pleomorphism of cells. The mean endothelial hexagonality percentage in a study by Uçakhan et al. [27] by confocal microscopy was statistically significantly lower in $\mathrm{KC}$ eyes than in control eyes $(P<0.05)$ and was lower in severe $\mathrm{KC}$ but this difference was not of clinical significanc. El-Agha et al. [26] found that the percentage for hexagonal cells can range from 38 to 78 and it may be higher in stage 1 compared to in stages 2 and 3. However, this difference was not significant $(p=0.51)$. Comparing mild-to-moderate KC (stages 1 and 2) with severe $\mathrm{KC}$ (stage 3 ), the difference was also not of statistical significance $(p=0.4)$.

\section{Conclusions}

From this study, we concluded that qualitative and quantitative structural changes were observed in endothelial cells of eyes with KC. In stages one and two, KC does not significantly affect the corneal endothelim. The endothelium in stage 3 shows significant changes regarding polymegathism and pleomorphism. Our study can recommend that penetrating keratoplasty maybe superior to DALK in the management of stage 3 keratoconus as the endothelial cells changes will interfere with the stability of DALK. This recommendation needs further studies with long durations of follow up.

\section{Abbreviations}

KC: Keratoconus; CD: Cell Density; CV: Coefficient of Variation; ANOVA: Oneway Analysis of Variance; ECD: Endothelial cell density

\section{Acknowledgments}

Nothing to be acknowledged.

\section{Authors' contributions}

AE: Set the idea and concept of the study, shared in writing the manuscript and analysis of the data, revised and edited the manuscript and collection of data revised and edited the manuscript, revised the statistical analysis, data collection and writing the manuscript. He read and approved the manuscript. AO: He shared in writing the manuscript and analysis of the data, revised and edited the manuscript and collection of data revised and edited the manuscript, revised the statistical analysis, data collection and writing the manuscript. He read and approved the manuscript. MS: He shared in writing the manuscript and analysis of the data, revised and edited the manuscript and collection of data revised and edited the manuscript, revised the statistical analysis, data collection and writing the manuscript. He read and approved the manuscript. M Elm: He shared in writing the manuscript and analysis of the data, revised and edited the manuscript and collection of data revised and edited the manuscript, revised the statistical analysis, data collection and writing the manuscript. He read and approved the manuscript. MK: she shared in writing the manuscript and analysis of the data, revised and edited the manuscript and collection of data revised and edited the manuscript, revised the statistical analysis, data collection and writing the manuscript. He read and approved the manuscript. MYH: He shared in writing the manuscript and analysis of the data, revised and edited the manuscript and collection of data revised and edited the manuscript, revised the statistical analysis, data collection and writing the manuscript. He read and approved the manuscript. M Elk: He shared in writing the manuscript and analysis of the data, revised and edited the manuscript and collection of data revised and edited the manuscript, revised the statistical analysis, data collection and writing the manuscript. He read and approved the manuscript.

Funding

None.

Availability of data and materials

The data used to support the findings of this study are available from the corresponding author upon request.

\section{Declarations}

\section{Ethics approval and consent to participate}

All procedures performed in studies involving human participants were in accordance with the ethical standards of Alexandria Faculty of Medicine ethics committee and with the 1964 Helsinki declaration and its later amendments. The ethical approval was obtained from the ethics committee of Alexandria Faculty of Medicine, Alexandria, Egypt. A written informed consent was obtained from all individual participants included in the study.

Consent for publication

Not Applicable.

\section{Competing interests}

The authors declare no competing financial issues.

\section{Author details}

${ }^{1}$ Department of Ophthalmology, Faculty of Medicine, Alexandria University, Champollion Street, Al Attarin, Alexandria, Egypt. Department of Ophthalmology, Tanta University, Tanta, Egypt. ${ }^{3}$ Department of 
Ophthalmology, Port Said University, Port Fuad, Egypt. ${ }^{4}$ Alex I-Care Hospital, Alexandria, Egypt.

Received: 26 October 2020 Accepted: 12 March 2021

Published online: 21 March 2021

\section{References}

1. Georgiou T, Funnell CL, Cassels-Brown A, O'Conor R. Influence of ethnic origin on the incidence of keratoconus and associated atopic disease in Asians and white patients. Eye. 2004;18(4):379-83. https://doi.org/10.1038/sj. eye.6700652.

2. Grünauer-Kloevekorn C, Duncker G. Keratokonus: Epidemiologie, Risikofaktoren und Diagnostik. Klin Monatsbl Augenheilkd. 2006;223(6):493502. https://doi.org/10.1055/s-2005-859021.

3. Jensen $L B$, Hjortdal J, Ehlers N. Longterm follow-up of penetrating keratoplasty for keratoconus. Acta Ophthalmol. 2010;88(3):347-51. https:// doi.org/10.1111/j.1755-3768.2009.01525.x.

4. Karamichos D. Keratoconus: In vitro and in vivo. Jacobs J Ophthalmol. 2015; $1(1)$.

5. Kennedy RH, Bourne WM, Dyer JA. A 48-year clinical and epidemiologic study of Keratoconus. Am J Ophthalmol. 1986;101(3):267-73. https://doi. org/10.1016/0002-9394(86)90817-2.

6. McGhee CNJ. 2008 sir Norman McAlister Gregg lecture: 150 years of practical observations on the conical cornea - what have we learned? Clin Exp Ophthalmol. 2009;37(2):160-76. https://doi.org/10.1111/j.1442-9071.2 009.02009.x.

7. Nielsen K, Hjortdal J, Aagaard Nohr E, Ehlers N. Incidence and prevalence of keratoconus in Denmark. Acta Ophthalmol Scand. 2007;85(8):890-2. https:// doi.org/10.1111/j.1600-0420.2007.00981.x.

8. Owens $\mathrm{H}$, Gamble G. A profile of Keratoconus in New Zealand. Cornea. 2003;22(2):122-5. https://doi.org/10.1097/00003226-200303000-00008.

9. Tan B, Baker K, Chen Y-L, Lewis JWL, Shi L, Swartz T, Wang M. How keratoconus influences optical performance of the eye. J Vis. 2008;8(2):13. https://doi.org/10.1167/8.2.13.

10. Zadnik K, Barr JT, Edrington TB, Everett DF, Jameson M, McMahon TT, Shin $J A$, Sterling $J$, Wagner $\mathrm{H}$, Gordon MO. Baseline findings in the collaborative longitudinal evaluation of Keratoconus (CLEK) study. Invest Ophthalmol Vis Sci. 1998;39(13):2537-46.

11. Cingu AK, Cinar Y, Turkcu FM, Sahin A, Ari S, Yuksel H, Sahin M, Caca !. Effects of vernal and allergic conjunctivitis on severity of keratoconus. Int J Ophthalmol. 2013;6(3):370-4. https://doi.org/10.3980/j.issn.2222-3959.2013. 03.21

12. Colby K, Dohlman C. Vernal Keratoconjunctivitis. Int Ophthalmol Clin. 1996; 36(1):15-20. https://doi.org/10.1097/00004397-199603610-00004.

13. Gordon-Shaag A, Millodot M, Shneor E. The epidemiology and etiology of Keratoconus. Int J Keratoconus Ectatic Corneal Dis. 2012;1 (1):7-15.

14. Thoft RA. The cornea: scientific foundations and clinical practice: Lippincott Williams \& Wilkins; 2005.

15. Salvetat ML, Zeppieri M, Miani F, Parisi L, Felletti M, Brusini P. Comparison between laser scanning in vivo confocal microscopy and noncontact specular microscopy in assessing corneal endothelial cell density and central corneal thickness. Cornea. 2011;30(7):754-9. https://doi.org/10.1097/ ICO.0b013e3182000c5d.

16. Sarnicola V, Toro P, Sarnicola C, Sarnicola E, Ruggiero A. Long-term graft survival in deep anterior lamellar Keratoplasty. Cornea. 2012;31(6):621-6. https://doi.org/10.1097/ICO.0b013e31823d0412.

17. Borderie VM, Sandali O, Bullet J, Gaujoux T, Touzeau O, Laroche L. Longterm results of deep anterior lamellar versus penetrating Keratoplasty. Ophthalmology. 2012;119(2):249-55. https://doi.org/10.1016/j.ophtha.2011. 07.057.

18. Cheng YYY, Visser N, Schouten JS, Wijdh R-J, Pels E, van Cleynenbreugel H, Eggink CA, Zaal MJW, Rijneveld WJ, Nuijts RMMA. Endothelial cell loss and visual outcome of deep anterior lamellar Keratoplasty versus penetrating Keratoplasty: a randomized multicenter clinical trial. Ophthalmology. 2011; 118(2):302-9. https://doi.org/10.1016/j.ophtha.2010.06.005.

19. Kubaloglu A, Koytak A, Sari ES, Akyol S, Kurnaz E, Ozerturk Y. Corneal endothelium after deep anterior lamellar keratoplasty and penetrating keratoplasty for keratoconus: a four-year comparative study. Indian J Ophthalmol. 2012;60(1):35-40. https://doi.org/10.4103/0301-4738.90490.
20. Matsuda M, Suda T, Manabe R. Quantitative analysis of endothelial mosaic pattern changes in anterior Keratoconus. Am J Ophthalmol. 1984;98(1):43-9. https://doi.org/10.1016/0002-9394(84)90187-9.

21. Laing RA. The human corneal endothelium in Keratoconus. Arch Ophthalmol. 1979:97(10):1867. https://doi.org/10.1001/archopht.1979.0102 0020315005.

22. Armstrong RA. Statistical guidelines for the analysis of data obtained from one or both eyes. Ophthalmic Physiol Opt. 2013;33(1):7-14. https://doi.org/1 0.1111/opo.12009

23. Murdoch IE, Morris SS, Cousens SN. People and eyes: statistical approaches in ophthalmology. Br J Ophthalmol. 1998;82(8):971-3. https://doi.org/10.113 6/bjo.82.8.971

24. Timucin OB, Karadag MF, Cinal A, Asker M, Asker S, Timucin D. Assessment of corneal endothelial cell density in patients with keratoconus not using contact lenses. Contact Lens Anterior Eye. 2013;36(2):80-5. https://doi.org/1 0.1016/j.clae.2012.10.081

25. Niederer RL, Perumal D, Sherwin T, McGhee CNJ. Laser scanning in vivo confocal microscopy reveals reduced innervation and reduction in cell density in all layers of the Keratoconic cornea. Invest Opthalmol Visual Sci. 2008:49(7):2964. https://doi.org/10.1167/iovs.07-0968.

26. El-Agha M-SH, El Sayed YM, Harhara RM, Essam HM. Correlation of corneal endothelial changes with different stages of Keratoconus. Cornea. 2014; 33(7):707-11. https://doi.org/10.1097//CO.0000000000000134.

27. Uakhan MR, Kanpolat A, YImaz NL, Zkan M. In vivo confocal microscopy findings in Keratoconus. Eye Contact Lens. 2006;32(4):183-91. https://doi. org/10.1097/01.icl.0000189038.74139.4a.

28. Bitirgen G, Akpinar Z, Malik RA, Ozkagnici A. Use of corneal confocal microscopy to detect corneal nerve loss and increased dendritic cells in patients with multiple sclerosis. JAMA Ophthalmol. 2017;135(7):777-82. https://doi.org/10.1001/jamaophthalmol.2017.1590.

29. Hollingsworth JG, Efron N, Tullo AB. In vivo corneal confocal microscopy in keratoconus. Ophthalmic Physiol Opt. 2005;25(3):254-60. https://doi.org/1 0.1111/j.1475-1313.2005.00278.x.

30. Halabis JA. Analysis of the corneal endothelium in Keratoconus. Optom Vis Sci. 1987;64(1):51-3. https://doi.org/10.1097/00006324-198701000-00009.

\section{Publisher's Note}

Springer Nature remains neutral with regard to jurisdictional claims in published maps and institutional affiliations.

Ready to submit your research? Choose BMC and benefit from:

- fast, convenient online submission

- thorough peer review by experienced researchers in your field

- rapid publication on acceptance

- support for research data, including large and complex data types

- gold Open Access which fosters wider collaboration and increased citations

- maximum visibility for your research: over $100 \mathrm{M}$ website views per year

At BMC, research is always in progress.

Learn more biomedcentral.com/submission 